\title{
Effect of the odour of female rat urine on plasma testosterone concentrations in male rats
}

\author{
K. Purvis* and N. B. Haynes \\ Department of Physiology and Environmental Studies, University of Nottingham, \\ School of Agriculture, Sutton Bonington, Nr. Loughborough, Leicestershire, U.K.
}

Summary. Testosterone levels were significantly higher in males, regardless of sexual experience, exposed to the odour of urine from females than in those exposed to saline or kept in ordinary groups.

\section{Introduction}

There are numerous reports that proximity to a female without physical contact can cause increases in plasma LH and testosterone levels in males of many species (see Illius, Haynes \& Lamming, 1976). Reports on which factors are responsible, however, are limited. Vaginal odour will elicit a testicular response in hamsters (Macrides, Bartke, Fernandez \& D'Angelo, 1974), and Maruniak \& Bronson (1976) have shown that female urine will cause transient increases in plasma $\mathrm{LH}$ in male mice. This communication describes experiments to investigate the role of female urine in causing elevated plasma testosterone concentrations in male rats.

\section{Materials and Methods}

The apparatus used is shown in Text-fig. 1. A similar second apparatus was placed adjacent to the first but was separated from it by a partition. Urine was prevented from passing through the apparatus by absorbent pads below the floor of the upper cage and urine flow was mimicked by a slow passage of saline.

The 112-day-old male rats (from the Sutton Bonington colony of Wistar origin) were randomly allocated to 6 groups of 8 each and were then treated as follows.

Those in Group A were placed in the apparatus and exposed for 4 days to the urine from 5 ovariectomized females in which oestrus was induced by subcutaneous injections of $10 \mu \mathrm{g}$ oestradiol$17 \beta$ in $0.25 \mathrm{ml}$ arachis oil $42 \mathrm{~h}$ and $18 \mathrm{~h}$ before and $1.0 \mathrm{mg}$ progesterone in $0.25 \mathrm{ml}$ arachis oil at the start of the experiment. Rats in Group B were exposed to saline $(0 \cdot 15 \mathrm{M}-\mathrm{NaCl})$ for 4 days: oestrous females were housed above these animals to standardize the possible effects of auditory communication between males and females. In Group $\mathrm{C}$ the males were housed away from the apparatus in a communal cage to evaluate the effects of non-olfactory communication in the other groups. Males in Groups D, E and F were treated similarly but were given sexual experience by association with females for 4 days (4-females with each group of 8 males). A 7-day interval was then allowed before participation in the experiment. After 4 days all males were bled from the jugular vein (between 14:00 and 16:00 h) immediately after ether anaesthesia. Blood plasma was stored at $-20^{\circ} \mathrm{C}$ until assayed for testosterone by a competitive protein-binding method described in detail elsewhere (Purvis \& Haynes, 1974). The assay used human pregnancy plasma as a source of binding protein and incorporated a thin-layer chromatography step which adequately separated testosterone from interfering steroids. The assay was sensitive to $0.5 \mathrm{ng}$ testosterone and had a coefficient of variation of $10.6 \%$ over the range measured. Statistical evaluation was by analysis of variance.

\footnotetext{
* Present address: Institute of Pathology, Riks Hospital, Oslo, Norway.
} 


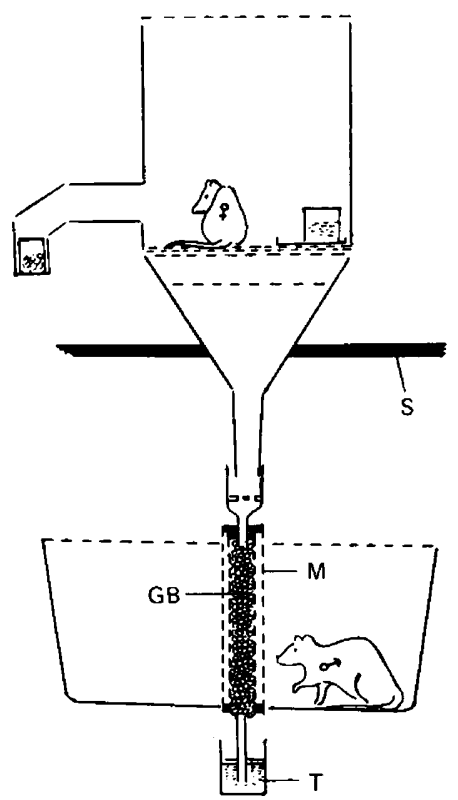

Text-fig. 1. Apparatus used to facilitate exposure of groups of male rats to the odour of the urine of females. A perforated metal tube containing glass beads $(\mathrm{GB})$ allows the female rat urine to percolate to a trap (T). The glass-bead column forms the centre of the cage housing the males. A wire mesh cylinder (M) surrounding the column prevents rats licking the urine. Visual communication between animals in the upper and lower cages is prevented by screens (S).

\section{Results}

These are shown in Table 1. Plasma testosterone concentrations were higher in males exposed to the urine of females.

Table 1. Mean ( \pm s.e.m.) plasma testosterone concentrations of sexually naive and experienced male rats exposed to the odour of saline or urine from female rats

\begin{tabular}{llc}
\hline \multicolumn{1}{c}{ Treatment } & Group & $\begin{array}{c}\text { Testosterone conc. } \\
(\mathrm{ng} / \mathrm{ml})\end{array}$ \\
\hline Sexually naive & & \\
$\quad$ Exposed to female urine & A & $8 \cdot 11 \pm 1 \cdot 11^{\mathrm{a}}$ \\
$\quad$ Exposed to saline & B & $4.23 \pm 0.73^{\mathrm{b}}$ \\
Control & $\mathrm{C}$ & $4.77 \pm 0.46^{\mathrm{b}}$ \\
Sexually experienced & & \\
$\quad$ Exposed to female urine & D & $8.55 \pm 0.73^{\mathrm{a}}$ \\
Exposed to saline & E & $4.01 \pm 0.53^{\mathrm{b}}$ \\
Control & F & $5.59 \pm 0.65^{\mathrm{c}}$ \\
\hline
\end{tabular}

Values designated by superscript ' $a$ ' are significantly greater than those designated ' $b$ ' $(P<0.01)$ and 'c' $(P<0.02)$. 


\section{Discussion}

The data suggest that elevation of plasma testosterone in male rats associated with females may result from a factor in female rat urine. This is in agreement with the observations of Maruniak \& Bronson (1976) in relation to LH in male mice and likewise the extensive documentation on male urine as a potent source of pheromones affecting the endocrinology of the female (see Whitten \& Champlin, 1973). Although involvement of female urine is implicated, the possibility of synergism between olfactory and, for instance, auditory stimuli being needed to elevate testosterone concentrations is not ruled out. That sexual experience is not necessary for the response also accords with the data of Maruniak \& Bronson (1976). These authors also showed that the physiological status of the female producing the urine was immaterial. Whilst not investigated specifically, this could be the case in the current study since the female rats produced 'oestrous' urine for the first half of the exposure period at most and 'spayed' urine thereafter. The observation that testosterone is elevated 4 days after the start of the experiment differs from a number of other reports on male (female) association in which the effects appear to be transitory, lasting not more than a few hours (Katongole, Naftolin \& Short, 1971; Macrides, Bartke \& Dalterio, 1975; Kamel, Mock, Wright \& Frankel, 1975). However, most of these experiments were carried out with a one-to-one ratio of males to females. For example, association of one male rat with one female causes elevations in testosterone lasting about $1 \mathrm{~h}$ (Purvis \& Haynes, 1974 ) but in the same situation there is only a trend towards elevated testosterone after 4 days (Purvis \& Haynes, 1972). Two reasons could be responsible for this difference. Firstly, males in the current experiment were subjected to urine from a number of different females which could facilitate the response, and prevent habituation, to a specific stimulus. Secondly, grouped males may be in a social situation which is aggravated by the presence of female urine, and peripheral plasma testosterone may be stimulated by increased aggression. This is in accord with observations that grouped rams in the proximity of grouped ewes become more aggressive than controls and maintain a higher plasma testosterone concentration for months (Illius, Haynes \& Lamming, 1976).

\section{References}

Illius, A.W., Haynes, N.B. \& Lamming, G.E. (1976) Effects of ewe proximity on peripheral plasma testosterone levels and behaviour in the ram. $J$. Reprod. Fert. 48, 25-32.

Kamel, F., Mock, E.J., Wright, W.W. \& Frankel, A.I. (1975) Alterations in plasma concentrations of testosterone, $\mathrm{LH}$ and prolactin associated with mating in the male rat. Horm. \& Behal. 6, 277-288.

Katongole, C.B., Naftolin, F. \& Short, R.V. (1971) Relationship between blood levels of luteinizing hormone and testosterone in bulls and the effects of social stimulation. J. Endocr. 50, 101-106.

Macrides, F., Bartke, A., Fernandez, F. \& D'Angelo, W. (1974) Effects of exposure to vaginal odour and receptive females on plasma testosterone in the male hamster. Neturoendocrinology 15, 355-364.

Macrides, F., Bartke, A. \& Dalterio, S. (1975)
Strange females increase plasma testosterone level in male mice. Science, N.Y. 189, 1104-1105.

Maruniak, J.A. \& Bronson, F.H. (1976) Gonadotropic responses of male mice to female urine. Endocrinology 99, 963-969.

Purvis, K. \& Haynes, N.B. (1972) The effect of female rat proximity on the reproductive system of male rats. Physiol. Behav. 9, 401-407.

Purvis, K. \& Haynes, N.B. (1974) Short-term effects of copulation, human chorionic gonadotrophin injection and non-tactile association with a female on testosterone levels in the male rat. J. Endocr. 60, 429439.

Whitten, W.K. \& Champlin, A.K. (1973) The role of olfaction in mammalian reproduction. In Handbook of Physiology, Section 7, Vol. II, part i, Endocrinology pp. 109-123. American Physiological Society, Washington. D.C.

Received 19 August 1977 